\title{
COVID-19 PANDEMIC PUBLICATION DURING 2020 IN INDONESIA (A BIBLIOMETRICS STUDY)
}

\author{
Ayu Trysnawati* \& Karmila Pare Allo** \\ *Jurusan Ilmu Perpustakaan Universitas Islam Negeri Alauddin Makassar \\ *UPT Perpustakaan Universitas Islam Negeri Alauddin Makassar \\ Email:ayu.trysnawati@uin-alauddin.ac.id,karmila.pare.allo@uin-alauddin.ac.id
}

(Submitted: 08-12-2020, Revised: 25-12-2020, Accepted: 25-08-2020)

DOI: $10.24252 /$ kah.v8i2a9

\begin{abstract}
ABSTRAK: Covid-19 dinyatakan sebagai wabah pandemi oleh WHO sejak awal tahun ini. Di Indonesia sendiri, pernyataan resmi dari pemerintah bahwa Covid-19 telah masuk ke negara ini adalah pada Maret 2020. Sejak itu, wabah ini menjadi isu yang banyak dikaji dari berbagai disiplin ilmu. Penelitian ini menggambarkan tren perkembangan publikasi jurnal di Indonesia; kolaborasi penulis, bentuk publikasi, dan sebaran disiplin ilmu. Data penelitian diperoleh melalui GARUDA (Garba Rujukan Digital) dari bulan Maret hingga akhir Oktober 2020 di mana terdapat sebanyak 326 publikasi jurnal bertemakan pandemi Covid-19. Dengan bantuan Ms. Excel, data dianalisis menggunakan statistik sederhana. Hasil penelitian ini menemukan bahwa terdapat 688 penulis secara total, baik penulis individu maupun penulis gabungan dari ke 326 publikasi jurnal. Tingkat kolaborasi penulis adalah 0,561 atau sebesar $56,1 \%$, hal ini menunjukkan bahwa artikel yang ditulis kolaboratif lebih banyak daripada ditulis secara individu. Bentuk publikasi banyak yang merupakan artikel hasil penelitian dibandingkan dengan kajian literatur bertema pandemi Covid-19. Tiga bidang ilmu yang paling banyak memublikasikan tema pandemi Covid-19 ialah pendidikan, hukum, dan kesehatan.
\end{abstract}

Kata kunci: Covid-19; Bibliometrika

ABSTRACT: The Covid-19 was declared as a pandemic outbreak by WHO at the beginning of this year. In Indonesia, the government officially stated that the Covid-19 had entered the country was in March 2020. Since then, this outbreak has become an issue that has been widely studied in various disciplines. This research describes the trend of journal publication on the covid-19 pandemic in Indonesia; authors collaboration, publication form, and distribution of disciplines. The data were obtained through GARUDA (Garba Rujukan Digital/Digital Reference Site) published from March to the end of October 2020, where there were 326 journal publications with the theme of the Covid-19 pandemic. With Ms. Excel, the data were analyzed using simple statistics. The results found that there was a total of 688 authors, both individual or collaborative authors from 326 journal publications. The author collaboration rate was 0.561 or $56.1 \%$. It indicates that there were more collaborative articles than written individually. Many forms of publication were research articles compared to literature reviews on the theme of the Covid-19 pandemic. The discipline fields of science that most published the Covid-19 pandemic theme were education, law, and health.

Keywords: Covid-19; Bibliometrics

\section{PENDAHULUAN}

Covid-19 atau Coronavarius Disease 2019 adalah jenis penyakit baru yang belum pernah teridentifikasi oleh manusia yang menyerang sistem pernapasan. Covid-19 pertama kali ditemukan di Kota Wuhan, China pada akhir Desember 2019 lalu. Virus ini menular dengan 
sangat cepat dan telah menyebar ke hampir semua negara, termasuk Indonesia. Pada bulan Maret 2020 pemerintah secara resmi mengumumkan bahwa Covid-19 telah masuk ke Indonesia. World Health Organization (WHO) juga mengumumkan Covid-19 sebagai pandemi atau epidemi yang terjadi di seluruh dunia, atau di wilayah yang sangat luas, melintasi batas internasional dan biasanya menjangkiti banyak orang (Last JM, 2001), sehingga wabah ini ditetapkan sebagai keadaan darurat global. Hal ini membuat pemerintah di tiap-tiap negara mengambil beberapa kebijakan dengan tujuan untuk mencegah penyebaran virus Covid-19.

Hingga saat ini Covid-19 masih menjadi pusat perhatian setiap orang, terkhusus bagi para ilmuwan/akademisi dari berbagai disiplin ilmu, tidak hanya pada disiplin virologi semata atau disiplin ilmu lainnya yang serumpun. Beragam kajian telah dilakukan dan dipublikasikan. Sebuah studi baru memperkirakan bahwa terdapat 23.634 artikel unik yang dipublikasikan dan telah terindeks di Web of Science dan Scopus antara 1 Januari dan 30 Juni 2020 (Teixeira da Silva, Tsigaris, \& Erfanmanesh, 2020). Penelitian tersebut menganalisis 12.331 artikel virus corona di Web of Science dan 12.602 makalah yang dilacak oleh Scopus yang telah diterbitkan pada enam bulan periode 2020. Makalah penelitian masing-masing menyumbang $48 \%$ dan $37 \%$ dari semua artikel terkait Covid-19 di Scopus dan Web of Science. Surat, review, editorial dan catatan merupakan bagian artikel virus corona lainnya pada setiap database. Di kedua database tersebut, Amerika Serikat, China, dan Italia menjadi negara terdepan dengan volume penerbitan, sedangkan BMJ, Journal of Medical Virology, dan The Lancet menerbitkan paling banyak makalah terkait virus corona.

Melihat kajian tersebut di atas menunjukkan bahwa isu covid-19 menjadi tema yang paling banyak dituliskan oleh orang-orang. Setiap orang, apakah ia seorang akademisi, praktisi, peneliti, ataupun seorang penulis yang dengan kapasitasnya masing-masing menjadikan covid19 sebagai bagian pada tulisannya masing-masing. Maka tidak heran angka publikasi yang disebutkan pada kajian tersebut di atas sangat banyak. Dan, tentu saja angka publikasi tersebut terus bertambah, meskipun covid-19 tidak menjadi sebuah pandemi lagi.

Nasution (2017) mengatakan karya ilmiah merupakan salah satu indikator yang menjadi tolak ukur kemajuan pendidikan pada suatu bidang ilmu. Hasil penelitian yang dimuat pada portal jurnal dan hadir dalam bentuk artikel tentunya memberikan manfaat yang besar pada siapa saja. Suryoputro, Riadi dan Sya'ban (2012) mengatakan jurnal ilmiah adalah sebuah publikasi yang diterbitkan secara berkala oleh suatu organisasi yang memuat artikel hasil penelitian dalam suatu bidang tertentu.

Artikel merupakan sumber informasi primer yang dihasilkan penulis yang dapat memberikan kostribusi untuk perkembangan ilmu pengetahuan di bidangnya masing-masing. Banyaknya artikel yang dimuat dalam berbagai database elektronik dan dapat diakses dengan mudah secara online merupakan bentuk dari hasil proses perkembangan suatu bidang ilmu pengetahuan. Penelitian ini dilakukan untuk kepentingan orang lain yang memerlukannya terutama untuk generasi sekarang dan generasi yang akan datang.

Artikel ini secara khusus mengkaji sesuai dengan kondisi yang terjadi pada saat ini dengan tema pandemi Covid-19 pada tahun 2020. Publikasi penelitian ilmiah merupakan hal yang sangat penting. Tanpa publikasi, temuan hasil penelitian hanya diketahui oleh peneliti yang melakukan penelitian. Namun, dengan publikasi, temuan hasil penelitian dapat diketahui oleh publik. Kemudian publikasi tersebut dapat dievaluasi, didebat, disanggah, dikembangkan, atau dimanfaatkan (Anam, 2019).

Kolaborasi penulis merupakan kerjasama antara lebih dari satu orang dalam suatu kegiatan penelitian (Zebua, 2018). Salah satu metode yang banyak digunakan untuk menghitung tingkat kolaborasi penulis adalah bibliometrik yang merupakan kajian yang mengaplikasikan metode matematika dan statistik untuk mengukur suatu perubahan baik secara kuantitatif maupun kualitatif pada dokumen ataupun media lainnya. Metode ini memanfaatkan data bibliografi dari dokumen penelitian sebagai masukan indikator kolaborasi (Sulistyo-Basuki, 2002). Kolaborasi 
merupakan bagian yang esensial dari sebuah proses penelitian. (Violanti dalam Oyeniyi dalam Rahayu, 2018).

Bibliometrik digunakan untuk menganalisis publikasi akademik sebagai proses informasi, menggunakan pola dan dinamika yang diidentifikasi dalam upaya publikasi ilmiah sebagai proksi untuk pengembangan disiplin yang dianalisis (Pattah, 2013). Bibliometrik mengkaji distribusi publikasi secara kuantitatif terhadap literatur, sehingga bibliometrik dikenal memiliki tiga dalil dasar dalam analisis kuantitatifnya (Lolytasari, 2017) dan (Jones, 2016), juga dapat digunakan untuk menyurvei mana kontributor (misalnya penulis, atau lembaga) yang paling besar memberikan kontribusi (Andersen, 2018). Bibliometrika adalah metode yang digunakan untuk mempelajari atau mengukur teks dan informasi, yang telah menjadi alat standar kebijakan sains dan manajemen penelitian dalam beberapa dekade terakhir (Natakusumah, 2015).

Dari pemaparan di atas, menimbulkan beberapa pertanyaan yang membuat ketertarikan peneliti untuk mengetahui seberapa produktif penulis dalam melakukan penelitian dalam situasi pandemi Covid-19, kolaborasi penulis, mengetahui bentuk publikasi yang terbit, dan mengetahui bidang ilmu atau disiplin ilmu yang berkaitan. Penelitian ini diharapkan dapat dijadikan sebagai referensi untuk melihat bagaimana tren perkembangan publikasi yang bertema Covid-19 di Indonesia.

\section{METODOLOGI PENELITIAN}

Analisis bibliometrika dijadikan sebagai pendekatan yang bertujuan untuk mengetahui tren publikasi artikel tahun 2020 yang bertema pandemi Covid-19 dari berbagai bidang di Indonesia. Artikel penelitian dimuat dalam database online portal Garuda Ristek/Brin tahun 2020 berjumlah 326 artikel, sehingga sangat menarik untuk diketahui karakteristiknya. Adapun tujuan dari kajian ini untuk mengetahui kolaborasi penulis dan hasil penelitian yang merupakan hasil riset atau literatur pustaka. Sehingga, menunjukkan bagaimana tren publikasi artikel pada tahun 2020 yang bertema pandemi Covid-19 dari portal Garuda Ristek/Brin. Dengan demikian, kajian ini dapat menjadi memberi manfaat bagi peneliti lainnya dalam merencanakan kegiatan riset sesuai fokus utama.

Penelitian ini menggunakan metode kuantitatif dengan mengambil data melalui data base online, dengan tujuan mengetahui publikasi artikel yang terbit dengan tema pandemi Covid-19. Metode pengumpulan data pada kajian ini menggunakan dokumentasi, yaitu data yang berasal dari Portal Garuda Ristek/Brin pada tahun 2020. Data dikumpulkan dengan mencatat nama tiap penulis individu dan kolaborasi, judul artikel yang ditulis dan lembaga yang menerbitkan jurnal, kemudian diolah menggunakan Ms. Excel. Tujuannya untuk memudahkan pendistribusian data dan tampilan dalam format grafik. Selanjutnya data yang diperoleh dikelompokkan sesuai dengan variabel yang diteliti dan disajikan dalam bentuk tabel. Setelah diperoleh hasil dan dilakukan pembahasan, maka berikutnya adalah penarikan kesimpulan.

Adapun untuk menentukan tingkat kolaborasi menggunakan metode Subramanyam (1983), sebagai berikut:

Keterangan:

$$
C=\frac{N M}{N M+N S}
$$

C : Tingkat kolaborasi

NM : Total tulisan dengan penulis lebih dari 2 orang

NS : Total tulisan dengan penulis tunggal

a) Apabila nilai $\mathrm{C}=0$ maka dapat dikatakan bahwa hasil penelitian pada bidang tersebut seluruhnya dilakukan secara individual (penulis tunggal).

b) Apabila nilai $\mathrm{C}$ lebih besar dari nol dan kurang dari setengah $(0<\mathrm{C}<0,5)$ maka dapat dikatakan bahwa hasil penelitian yang dilakukan secara individual lebih besar dibandingkan dengan yang dilakukan secara berkolaborasi. 
c) Apabila nilai $\mathrm{C}=0,5$ maka penelitian yang dilakukan secara individu l s ama banyaknya dengan yang dilakukan secara berkolaborasi.

d) Apabila nilai $\mathrm{C}$ lebih besar dari 0,5 dan kurang dari $1(0,5<\mathrm{C}<1)$ dapat dikatakan bahwa hasil penelitian yang dilakukan secara individual lebih sedikit dibandingkan yang dilakukan secara berkolaborasi.

e) Apabila nilai $\mathrm{C}=1$ maka penelitian pada bidang tersebut seluruhnya dilakukan secara berkolaborasi (Sormin, 2009).

Hasil perhitungannya dianalisis dalam bentuk tabel agar dapat ditarik suatu kesimpulan (Rahayu \& Rachmawati, 2015).

\section{HASIL DAN PEMBAHASAN}

\section{Kolaborasi Penulis}

Jumlah penulis pada artikel yang dipublikasikan pada tahun 2020 dengan tema pandemi Covid-19 pada database online berjumlah 688 penulis. Perkembangan jumlah artikel pada bulan Maret sampai bulan September mengalami terus peningkatan. Untuk melihat jumlah penulis dapat dilihat pada tabel 1:

Tabel 1. Tingkat kolaborasi penulis

\begin{tabular}{clc}
\hline NO & NAMA & Jumlah \\
\hline 1 & Penulis Tunggal & 143 \\
2 & Penulis 2 Orang & 88 \\
3 & Penulis Kolaborasi >3 Orang & 95 \\
& TOTAL & 326
\end{tabular}

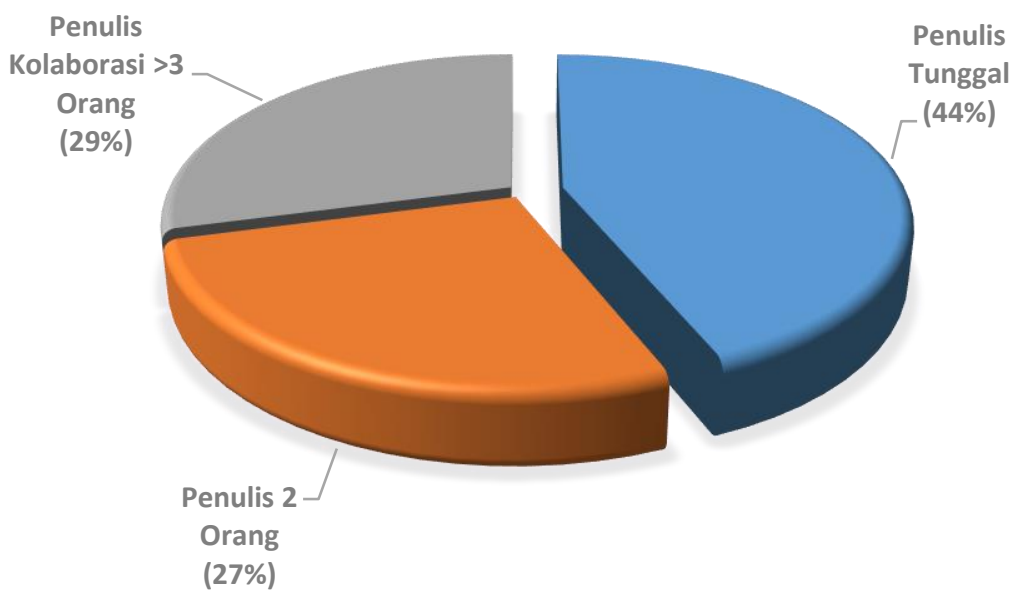

Grafik 1. Tingkat kolaborasi penulis

Tabel 1 dan Grafik 1 menunjukkan jumlah dan persentase kolaborasi penulis dari keseluruhan artikel yang dipublikasikan pada tahun 2020 dengan tema pandemi Covid-19. Jumlah artikel yang ditulis oleh penulis perorangan adalah sebanyak 143 artikel (44\%), kemudian diikuti oleh artikel yang ditulis oleh penulis kolaborasi lebih 2 sebanyak 95 artikel (29\%), dan diikuti oleh artikel penulis kolaborasi 2 sebanyak 88 artikel (27\%). Hal ini menunjukkan bahwa kepenulisan perorangan mempunyai peringkat teratas, urutan kedua adalah penulis kolaborasi lebih dari 2 orang dan yang urutan ketiga adalah penulis kolaborasi 
dengan 2 orang. Untuk lebih jelas pengelompokkan antara penulis perorangan dan gabungan, maka disajikan pada Tabel 2 berikut.

Tabel 2 Penulis perorangan dan gabungan

\begin{tabular}{cccc}
\hline NO & NAMA & Jumlah & \% \\
\hline 1 & Pengarang Perorangan & 143 & $44 \%$ \\
2 & Pengarang Gabungan & 183 & $56 \%$ \\
& TOTAL & 326 & $100 \%$ \\
\hline
\end{tabular}

Tabel 2 di atas menunjukkan bahwa dari 326 artikel yang diteliti, terdiri dari artikel yang ditulis penulis perorangan sebanyak 143 artikel (44\%) dan artikel yang ditulis penulis gabungan sebanyak 183 artikel (56\%). Hal ini menunjukkan bahwa penulis gabungan lebih mendominasi terbitan artikel yang bertema pandemi Covid-19 pada tahun 2020.

Untuk menentukan derajat/tingkat kolaborasi penulis secara kuantitatif dari Portal Garuda Ristek/Brin digunakan rumus Subramanyam berikut (Subramanyam, 1983):

$$
\begin{aligned}
& C=\frac{N M}{N M+N S} \\
& \text { Sehingga, } \\
& \begin{aligned}
C & =\frac{183}{183+143} \\
& =\mathbf{0 , 5 6 1} \text { atau } \mathbf{5 6 , 1 \%}
\end{aligned}
\end{aligned}
$$

Dari hasil perhitungan derajat/tingkat kolaborasi penulis pada keseluruhan publikasi maka ditemukan tingkat kolaborasi penulis adalah sebesar 0,561 atau 56,1\%. Ini menunjukkan bahwa jumlah artikel yang ditulis secara berkolaborasi antar 2 orang atau lebih penulis dengan yang ditulis oleh penulis tunggal hampir berimbang.

\section{Bentuk Artikel}

Jumlah artikel yang dipublikasikan pada tahun 2020 dengan tema pandemi Covid-19 pada Portal Garuda Ristek/Brin ditemukan sebanyak 326. Artikel tersebut tersebar dalam berbagai jurnal yang ada di Indonesia. Artikel ini terdiri dari dua hasil penelitian yaitu hasil penelitian riset dan literatur pustaka. Untuk melihat lebih jelas pengelompokkan antara hasil penelitian riset dan literatur pustaka maka disajikan pada Diagram 3 berikut.

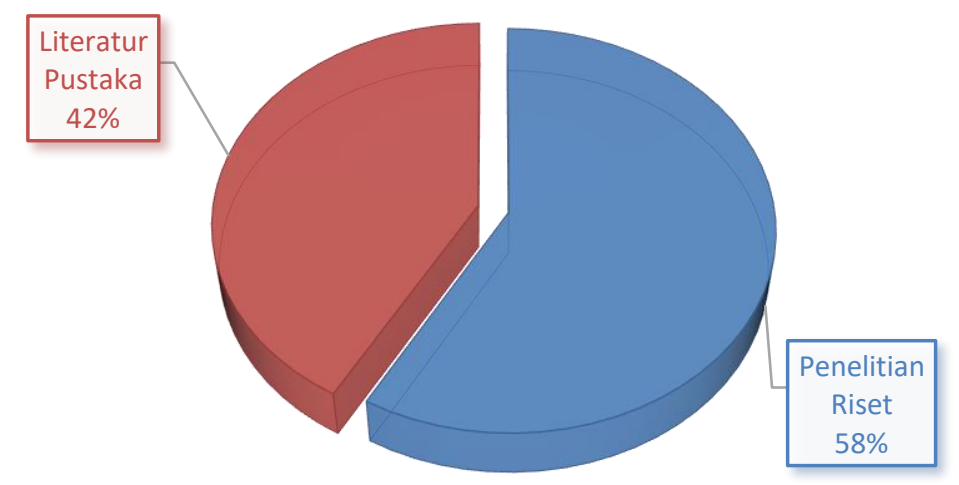


Diagram 3. Bentuk artikel

Diagram 3 di atas menunjukkan bahwa dari 326 artikel yang dipublikasikan terdapat sebanyak 190 (58\%) artikel yang merupakan hasil penelitian berbasis riset dan sisanya sebesar $136(42 \%)$ merupakan hasil penelitian berbasis literatur pustaka. Hal ini menunjukkan bahwa penelitian berbasis riset lebih mendominasi artikel yang terbit pada tahun 2020 yang bertema pandemi Covid-19.

\section{Disiplin Ilmu}

Antara Maret dan Oktober tahun 2020, terdapat 326 artikel yang telah terindeks pada portal Garuda Ristek/Brin, baik yang ditulis oleh penulis tunggal ataupun penulis kolaborasi. Dari kesemua itu, hasil penelitian lainnya menemukan bahwa terdapat berbagai macam disiplin ilmu yang berkontribusi dalam penulisan bertemakan covid-19, berikut diurutkan berdasarkan banyaknya publikasi yang telah dihasilkan.

Tabel 3. Disiplin ilmu

\begin{tabular}{|c|c|c|c|}
\hline No & Disiplin Ilmu & Total Publikasi & $\%$ \\
\hline 1 & Pendidikan & 90 & $27,61 \%$ \\
\hline 2 & Ilmu Hukum & 47 & $14,42 \%$ \\
\hline 3 & Kesehatan (Kedokteran dan Farmasi) & 40 & $12,27 \%$ \\
\hline 4 & Ekonomi dan Bisnis & 31 & $9,51 \%$ \\
\hline 5 & Sains dan Teknologi & 27 & $8,28 \%$ \\
\hline 6 & Ilmu Sosial dan Politik & 26 & $7,98 \%$ \\
\hline 7 & Ilmu Komunikasi & 16 & $4,91 \%$ \\
\hline 8 & Agama Islam & 15 & $4,60 \%$ \\
\hline 9 & Psikologi & 13 & $3,99 \%$ \\
\hline 10 & Teologi & 5 & $1,53 \%$ \\
\hline 11 & Hubungan Internasional & 4 & $1,23 \%$ \\
\hline 12 & Teknik Industri & 3 & $0,92 \%$ \\
\hline 13 & Ilmu Perpustakaan & 2 & $0,61 \%$ \\
\hline 14 & Teknik Sipil & 2 & $0,61 \%$ \\
\hline 15 & Pariwisata & 1 & $0,31 \%$ \\
\hline 16 & Linguistik & 1 & $0,31 \%$ \\
\hline 17 & Literasi & 1 & $0,31 \%$ \\
\hline 18 & Pertanian & 1 & $0,31 \%$ \\
\hline 19 & Ilmu Filsafat & 1 & $0,31 \%$ \\
\hline & TOTAL & 326 & $100 \%$ \\
\hline
\end{tabular}

Tabel 3 di atas menunjukkan bahwa ada 19 disiplin ilmu dari 326 artikel pada Portal Garuda/Ristek Brin. Adapun disiplin ilmu yang mendominasi adalah "pendidikan" sebanyak 90 (28\%) artikel, selanjutnya "ilmu hukum" sebanyak 47 (14\%) artikel, kemudian disusul oleh "kesehatan (kedokteran dan farmasi)" sebanyak 44 (13\%) artikel. Lalu "ekonomi dan bisnis" sebanyak 31 (10\%) artikel, "ilmu sosial dan politik" sebanyak 26 (8\%), kemudian "sains dan teknologi" sebanyak 27 (7\%) artikel, "agama Islam dan ilmu komunikasi" berada di peringkat yang sama yaitu sebanyak 5 \%. Selanjutnya "psikologi" sebanyak 13 (4\%) artikel, "teologi" sebanyak 5 (2\%) artikel, "hubungan internasional" sebanyak 4 (1\%) artikel. Kemudian pada peringkat yang sama yaitu "teknik industri" sebanyak 3 (1\%), "teknik sipil" dan "ilmu perpustakaan" sebanyak $2(1 \%)$ artikel dan beberapa disiplin ilmu yang lainnya yaitu 
"pariwisata", "lingusitik", "literasi", "pertanian" dan "ilmu filsafat" yang berada pada urutan terbawah. Hal ini menunjukkan bahwa disiplin ilmu yang paling banyak dipublikasikan adalah "pendidikan".

\section{KESIMPULAN}

Dari total 688 penulis yang berkontribusi menghasilkan 326 artikel terkait covid-19, tingkat kolaborasi penulis hampir seimbang antara tulisan yang dibuat secara kolaborasi (dua orang atau lebih dari dua orang) dengan tulisan dengan penulis tunggal. Untuk mendalami lebih jauh lagi kedua kategori tersebut, maka perlu ada kajian lanjutan. Tingkat kolaborasi tersebut adalah sebesar 0,561 atau 5,61\%. Sementara untuk bentuk artikel, artikel berbasis hasil penelitian lebih banyak dari yang hanya merupakan studi pustaka atau kajian literatur. Adapun untuk displin ilmu, terdapat 3 disiplin ilmu yang menduduki peringkat tiga besar yang melakukan penelitian dengan mengangkat isu Covid-19. Hal ini menunjukkan bahwa ketiga disiplin ilmu ini sangat berkaitan dan memiliki dampak secara langsung, misalnya mengenai pendidikan. Pada masa pandemi ini pemerintah menganjurkan untuk belajar dan bekerja dari rumah. Hal ini tentu memberikan tantangan bagi peneliti untuk mengkaji tentang pendidikan pada masa sekarang ini. Begitu juga dari sisi disiplin ilmu hukum yang begitu banyak aturan dan kebijakan dari pemerintah pada masa pandemi ini, sehingga banyak peneliti yang tertarik mengkaji Covid-19 dari sisi ilmu huku. Serta disiplin ilmu kesehatan yang tentunya berkaitan erat dengan Covid-19. Selain itu, penelitian ini terdapat beberapa disiplin ilmu yang berkaitan guna untuk melihat perkembangan bahan bacaan disiplin ilmu masing-masing. Bagi perpustakaan tentunya menyediakan koleksi sesuai dengan disiplin ilmu yang paling banyak melakukan penelitian sehingga memudahkan peneliti untuk mendapatkan bahan rujukan.

Melihat tren disiplin ilmu yang telah memberikan sumbangsih pemikiran, baik itu sekedar menggambarkan Covid-19 itu sendiri hingga ke pemberian solusi atau pencegahannya, hal ini menunjukkan bahwa Covid-19 menjadi isu yang sejak awal kehadirannya hingga saat ini terus dibahas yang bukan hanya dibahas oleh disiplin ilmu virologi semata dan sejenisnya, namun disiplin ilmu lainnya pun ikut berkontribusi pada isu ini bahkan memberikan tawaran solusi untuk pemecahan masalah pandemi ini.

\section{DAFTAR PUSTAKA}

Andersen, J. (2018). Research Management. Academic Press. https://doi.org/10.1016/C2015-000323-9.

Jones, A. W. (2016). Encyclopedia of Forensic and Legal Medicine. Elsevier.

Nasution, M, KM. (2017). Teknik Penulisan Karya Tulis Ilmiah.

Pattah, S.H. (2013). Pemanfaatan Kajian Bibliometrika Sebagai Metode Evaluasi dan Kajian Ilmu Perpustakaan dan Informasi. Khizanah al-Hikmah : Jurnal Ilmu Perpustakaan, Informasi dan Kearsipan, 1, 47-57

Rahayu, R. N., \& Rachmawati, R. (2015). Kolaborasi dan Produktivitas Penulis Artikel Visi Pustaka 2000-2014. Baca: Jurnal Dokumentasi dan Informasi, 36, 141-152.

Subramanyam, K. (1983). Bibliometrics Studies of Research Collaboration. Journal of Information Science, 6, 33-38.

Sulistyo-Basuki. (2002). Bibliometrika, Sainsmetrika dan Infometrika. Kumpulan Makalah Kursus Bibliometrika. Jakarta: Masyarakat Infometrika Indonesia.

Suryoputro, G., Riadi, S., \& Sya'ban, A. (2012) Menulis Artikel Untuk Artikel Jurnal Ilmiah. Jakarta: UHAMKA Press.

Sormin, R. (2009). Kajian Korelasi Antara Kolaborasi Peneliti dan Produktivitas Peneliti Lingkup Badan Litbang Pertanian. Jurnal Perpustakaan Pertanian, 18, 1-6.

Zebua, Rusdin. (2018). Analisis Bibliometrika dan Kolaborasi Penulis Terhadap Artikel Penelitian Penyakit Jantung Koroner di Indonesia Tahun 2013-2017 Menggunakan Database Online Proquest. Jurnal Imam Bonjol: Kajian Ilmu Informasi dan Perpustakaan

Last JM, editor. (2001) A dictionary of epidemiology, 4th edition. New York: Oxford University Press. 
Lolytasari, N. H. (2017). Produktivitas Dosen UIN Syarif Hidayatullah Jakarta pada JurnalTeriendeks SCOPUS: Suatu Kajian Bibliometrik. Al-Maktabah.

Natakusumah, E. K. (2015). Bibliometric Analysis of the INKOM JOURNAL (Analisis Bibliometrik Jurnal INKOM). BACA: Jurnal Dokumentasi dan Informasi.

Teixeira da Silva, J. A., Tsigaris, P., \& Erfanmanesh, M. (2020). Publishing volumes in major databases related to Covid-19. Scientometrics.

Anam, C. (2019). Dokumen Publikasi Ilmiah: Warisan yang Tak Ternilai Harganya. Berkala Fisika. 